УДК 342.9(477)

DOI https://doi.org/10.32837/pyuv.v0i2(27).185

\author{
О. В. Пєший \\ аспірант \\ Науково-дослідного інституту публічного права
}

\title{
ФОРМИ ДІЯЛЬНОСТІ МІНІСТЕРСТВА РОЗВИТКУ ГРОМАД І ТЕРИТОРІЙ
}

В Україні розпочалися масштабні реформи системи центральних органів виконавчої влади, які зумовлені потребою трансформації апарату національної держави з метою подолання корупції, інформатизації публічних правовідносин та побудови реально партнерських відносин між громадянами та публічною адміністрацією. Зокрема, Міністерство регіонального розвитку, будівництва та житлово-комунального господарства України отримало нову назву - Міністерство розвитку громад і територій. Звичайно, реформа полягає не тільки у зміні назви органу публічної адміністрації, головною є концептуальна зміна форм діяльності відповідного міністерства згідно із визначеними цілями та пріоритетами. Уряд оприлюднив Програму дій, яка визначає цілі та пріоритети діяльності протягом наступних п'яти років. Серед основних напрямів роботи Уряд визначив розвиток людського капіталу та економіки, євроінтеграцію, безпеку та рівень комфорту життя громадян. Перед Міністерством розвитку громад і територій поставлені такі цілі: українці матимуть комфортне та доступне житло; українці отримають якісні комунальні послуги; українці зменшать втрати при споживанні тепла, гарячого водопостачання та інших енергетичних ресурсів у будинках; українці будуть відповідально поводитися із побутовими відходами та не засмічуватимуть навколишній життєвий простір; українці житимуть у комфортних містах та селах; українці матимуть реальну змогу впливати на організацію свого життєвого простору як мешканці спроможних громад; українці, що мешкають у «депресивних регіонах", матимуть достатні можливості для розвитку [1]. Механізм досягнення поставлених цілей потребує належного наукового обгрунтування, визначення найоптимальніших правових способів (засобів) виконання поставлених перед публічною адміністрацією завдань, прогнозування можливих наслідків запланованих реформ та мінімізації негативного впливу на рівень соціальної захищеності населення, реалізації прав і свобод громадян. Вищезазначене зумовлює необхідність проведення спеціального наукового дослідження форм діяльності Міністерства розвитку громад і територій із метою визначення шляхів їх удосконалення, внесення відповідних змін до чинного законодавства.

Форми діяльності центральних органів виконавчої влади досліджуються в роботах фахівців у сфері державного управління та адміністративного права, серед яких роботи О. Бандурки, В. Бевзенка, С. Болдирєва, В. Величка, Н. Губерської, С. Гусарова, Р. Калюжного, Т. Коломоєць, В. Колпакова, А. Комзюка, О. Кузьменко, В. Курила, Д. Лук'янця, Д. Лученка, Р. Мельника, О. Миколенка, Н. Нижник, Д. Приймаченка, С. Серьогіної, С. Стеценко, М. Тищенка, А. Школика та інших вчених-адміністративістів. Серед спеціалізованих досліджень даної тематики варто зазначити роботи Н. Железняк «Правові та організаційні форми діяльності Міністерства юстиції України у здійсненні державної правової політики (теоретичні та практичні питання)» [2], О. Предместнікова «Особливості організаційних і матеріально-технічних форм діяльності органів юстиції України» [3], Д. Слинько «Форми здійснення правотворчого процесу в діяльності Міністерства внутрішніх справ України» [4].

Проте форми діяльності Міністерства розвитку громад і територій досліджені в науковій літератуpi фрагментарно, в рамках більш загальних тем, що актуалізує проведення цього дослідження.

Метою наукової публікації є дослідження форм діяльності Міністерства розвитку громад і територій, які регламентовані чинним законодавством та зумовлені основними напрямами реформування публічної адміністрації України, з урахуванням європейських та міжнародних стандартів.

Науковці у сфері державного управління визначають форми діяльності органів публічної адміністрації як зовнішне вираження однорідних дій, процедур, які здійснюють органи публічної влади, їх структурні підрозділи й посадові особи в процесі реалізації функцій і компетенції в правових і організаційних рамках, та поділяють їх на правові, організаційні та матеріально-технічні [5, с. 57-59].

До правових форм діяльності міністерства зараховують нормотворчу, правозастосовну, установчу та контрольну форми діяльності. Нормотворча форма діяльності міністерства реалізується шляхом ординарного, законопроектного та спеціального провадження. У межах ординарного провадження здійснюється видання міністром наказів, затвердження положень, інструкцій, правил та інших документів нормативно-правового характеру. Законопроектне провадження передбачає діяльність щодо розробки проектів законів Украї- 
ни. Розробка проектів урядових і президентських актів та їх внесення на розгляд Кабінету Міністрів у встановленому порядку здійснюється в рамках спеціального провадження.

Правозастосовна форма діяльності міністерства являє собою діяльність із реалізації нормативних приписів шляхом видання наказів індивідуального правовстановлюючого або правоохоронного характеру, доручень організаційно-розпорядчого характеру, надання спеціальних дозволів (ліцензій) на здійснення певного виду діяльності фізичним і юридичним особам, реєстрації актів, прав, об'єктів тощо.

Установча форма діяльності здійснюється як безпосередньо міністерством, так і через Кабінет Міністрів України. Вона пов'язана із провадженнями щодо формування структури цього органу, системи його територіальних органів, утворення, реорганізації, ліквідації підприємств, організацій та установ, що належать до сфери його управління, призначення їх керівників, погодження призначення на посади керівників структурних підрозділів місцевих державних адміністрацій [5, с. 59].

Контрольна форма діяльності міністерства конкретизується в нормотворчому та виконавчому провадженнях. Нормотворче провадження передбачає контроль керівника цього органу за діяльністю з видання правових актів його заступниками, керівниками структурних підрозділів, територіальних органів, структурних підрозділів місцевих держадміністрацій із правом їх скасування, якщо ці акти суперечать Конституції України, іншим актам законодавства. Виконавче провадження являє собою поточний контроль за ефективністю діяльності апарату, територіальних органів центрального органу виконавчої влади, структурних підрозділів місцевих держадміністрацій, підприємств, організацій та установ, що належать до його сфери управління. Це провадження застосовується міністрами також стосовно тих центральних органів виконавчої влади, діяльність яких вони спрямовують та координують.

Організаційні форми діяльності міністерства поділяються на основні та допоміжні. До основних варто зарахувати персональну діяльність міністра, заступників міністра, керівників структурних підрозділів апарату цього органу, територіальних органів, засідання колегіальних центральних органів виконавчої влади, засідання колегії, громадської ради, інших консультативних, дорадчих та допоміжних органів колегіального характеру центральних органів виконавчої влади [5, с. 59-60].

Допоміжними організаційними формами роботи міністерства є участь його керівництва в засіданнях колегій інших органів виконавчої влади, парламентських і комітетських засіданнях та слуханнях, робочі поїздки по країні, офіційні візити за кордон, участь у міжнародних переговорах, прийом громадян, проведення прес-конференцій, участь у роботі семінарів, конференцій, симпозіумів тощо.

До матеріально-технічних форм роботи міністерства належать: робота з депутатськими запитами, зверненнями, обробка інформації, підготовка звітів, ведення бухгалтерського обліку, статистичної звітності, електронного документообігу, діловодство, господарська робота [5, с. 59-62].

Таким чином, форми діяльності міністерства доцільно поділити на чотири основні групи:

- правові (юридично-значущі) форми діяльності - нормотворчість (міжвідомча і відомча), правозастосування (посвідчення юридичних фактів, вирішення юридичних конфліктів та притягнення винуватих осіб до юридичної відповідальності), установча, контрольно-наглядова діяльність та інтерпретаційна діяльність;

- організаційні - адміністративно-господарська (матеріально-технічне забезпечення діяльності міністерства) та організаційно-розпорядча діяльність (кадрове забезпечення діяльності міністерства та оперативне управління його діяльністю);

- інформаційні - оприлюднення публічної формації про діяльність міністерства (прес-конференції, прес-релізи, інформаційні стенди, ведення офіційного веб-сайту) та відповіді на звернення громадян та інформаційні запити щодо доступу до публічної формації;

- комунікаційні форми діяльності - налагодження комунікаційних зв'язків між міністерством та іншими органами публічної адміністрації та обмін інформаційними повідомленнями в рамках єдиної інформаційної системи електронного документообігу.

Форми діяльності Міністерства розвитку громад і територій відповідають завданням будь-якого міністерства, які визначені у ст. 7 Закону України «Про центральні органи виконавчої влади», згідно з якою основними завданнями міністерства як органу, що забезпечує формування та реалізує державну політику в одній чи кількох сферах, є: забезпечення нормативно-правового регулювання; визначення пріоритетних напрямів розвитку; інформування та надання роз'яснень щодо здійснення державної політики; узагальнення практики застосування законодавства, розроблення пропозицій щодо його вдосконалення та внесення в установленому порядку проектів законодавчих актів, актів Президента України, Кабінету Міністрів України на розгляд Президентові України та Кабінету Міністрів України; забезпечення здійснення соціального діалогу на галузевому рівні; здійснення інших завдань, визначених законами України [6].

Детально форми та напрями діяльності Міністерства розвитку громад і територій регламен- 
товані в чинному Положенні про Міністерство регіонального розвитку, будівництва та житлово-комунального господарства України. Зокрема, відповідно до п. 3 вказаного Положення основними завданнями Мінрегіону є:

- забезпечення формування та реалізація державної регіональної політики, державної житлової політики і політики у сфері будівництва, архітектури, містобудування, житлово-комунального господарства, зокрема щодо: територіальної організації влади, адміністративно-територіального устрою, розвитку місцевого самоврядування; благоустрою населених пунктів, поводження з побутовими відходами, технічної інвентаризації об’єктів нерухомого майна, питної води та питного водопостачання;

- забезпечення формування державної політики у сфері архітектурно-будівельного контролю та нагляду, контролю у сфері житлово-комунального господарства, у сфері ефективного використання паливно-енергетичних ресурсів, енергозбереження, відновлюваних джерел енергії та альтернативних видів палива;

- забезпечення технічного регулювання у сфеpi будівництва, містобудування, промисловості будівельних матеріалів, житлово-комунального господарства [7].

У п. 4 Положення про Міністерство регіонального розвитку, будівництва та житлово-комунального господарства України розкриваються та конкретизуються конкретні форми та способи діяльності Міністерства розвитку громад і територій. Зокрема, Мінрегіон відповідно до покладених на нього завдань:

- визначає пріоритетні напрями розвитку відповідних сфер діяльності (організаційна форма діяльності);

- затверджує державні будівельні норми, зокрема з питань реставрації, консервації, ремонту і пристосування пам'яток архітектури і містобудування, програми підвищення енергоефективності у будівельній галузі, кваліфікаційні вимоги до виконавців робіт, пов'язаних із створенням об'єктів архітектури тощо (нормотворча форма діяльності);

- розробляєі здійснює заходи, спрямовані на розбудову інфраструктури регіонів, розвиток міжрегіонального економічного співробітництва (організаційна та комунікаційна форми діяльності);

- сприяє комплексному соціально-економічному розвитку регіонів (організаційна форма діяльності);

- розробляє державну стратегію регіонального розвитку, щорічні плани заходів щодо ії реалізації, здійснює методологічне керівництво та координацію діяльності з підготовки регіональних стратегій розвитку (нормотворча, організаційна та комунікаційна форми діяльності);
- здійснює відповідно до законодавства проведення в установленому порядку моніторингу соціально-економічних та інших показників розвитку регіонів, розроблення за участю інших центральних органів виконавчої влади, відповідних місцевих органів виконавчої влади та органів місцевого самоврядування програм подолання депресивності територій і проведення моніторингу їх виконання (контрольно-наглядова та комунікаційна форми діяльності);

- здійснює повноваження центрального органу виконавчої влади з нормування у будівництві, управління у сфері містобудування шляхом планування територій на державному рівні, визначення державних інтересів для їх урахування під час розроблення містобудівної документації та проведення моніторингу за дотриманням законодавства у сфері містобудування, проведення містобудівного моніторингу на державному рівні, організаційне забезпечення 3 питань державної підтримки будівництва (придбання) доступного житла, формування житлового фонду соціального призначення, кредитування індивідуальних сільських забудовників, реконструкції кварталів (мікрорайонів) застарілого житлового фонду та реалізації інфраструктурних проектів, організаційне, науково-технічне забезпечення виконання завдань із реформування і розвитку житлово-комунального господарства, технічного регулювання стосовно будівельних виробів, будинків і споруд, розроблення технічних регламентів, заходи щодо створення безперешкодного життєвого середовища для осіб з обмеженими фізичними можливостями та інших маломобільних груп населення (нормотворча, контрольно-наглядова та організаційна форми діяльності);

- перевіряє в межах повноважень, передбачених законом, дотримання нормативних документів i нормативів обчислення вартості будівництва об'єктів, що споруджуються із залученням бюджетних коштів, коштів державних i комунальних підприємств, установ та організацій, кредитів, наданих під державні гарантії (контрольно-наглядова форма діяльності);

- подає Кабінету Міністрів України пропозиції щодо: актів законодавства з питань організації діяльності місцевих органів виконавчої влади та органів місцевого самоврядування; розмежування повноважень місцевих органів виконавчої влади та органів місцевого самоврядування; адміністративно-територіального устрою; об'єднання територіальних громад; нормативно-правового забезпечення 3 питань регіональної політики i місцевого самоврядування, державної підтримки розвитку місцевого самоврядування; нагляду за діяльністю органів місцевого самоврядування з питань здійснення наданих їм законом повноважень органів виконавчої влади; адаптації на- 
ціонального законодавства у сфері місцевого самоврядування до положень Європейської хартії місцевого самоврядування та інших міжнародних договорів; вдосконалення механізмів інвестування та фінансування в будівництві та житлово-комунальному господарстві; державних програм у сфері будівництва і житлово-комунального господарства; проведення експертизи і затвердження проектів будівництва; державного фінансування капітальних вкладень і договірних відносин у будівництві; здійснення архітектурно-будівельного контролю та нагляду, контролю у сфері житлово-комунального господарства; порядку формування цін (тарифів) на житлово-комунальні послуги, які підлягають регулюванню; забезпечення ефективного використання паливно-енергетичних ресурсів, енергозбереження, збільшення частки відновлюваних джерел енергії та альтернативних видів палива в енергетичному балансі України (нормотворча форма діяльності);

- веде містобудівний кадастр на державному рівні та забезпечує ведення Єдиного державного реєстру громадян, які потребують поліпшення житлових умов (організаційна форма діяльності);

- затверджує перелік базових організацій із науково-технічної діяльності в будівництві; подає відповідному центральному органу виконавчої влади пропозиції щодо призначення органів з оцінки відповідності вимогам технічних регламентів (організаційна форма діяльності);

- проводить у межах повноважень, передбачених законом галузеву експертизу науково-дослідних (науково-технічних) установ у галузі будівництва та житлово-комунального господарства, моніторинг реалізації Генеральної схеми планування території України та іншої містобудівної документації, вартості будівництва та тенденцій розвитку будівельної галузі, стану реформування та розвитку житлово-комунального господарства, підготовки та проходження опалювального сезону, розрахунків підприємств житлово-комунального господарства за енергоносії, а також оплати населенням, юридичними особами наданих їм житлово-комунальних послуг (контрольно-наглядова форма діяльності);

- розробляє та координує програми підвищення енергоефективності та енергозбереження в житлово-комунальному господарстві, обладнання житлових будинків засобами обліку і регулювання споживання води та теплової енергії; формує прогнозні баланси споживання теплової енергії (організаційна та комунікаційна форми діяльності);

- забезпечує виконання державних цільових програм у відповідних сферах, функціонування системи базових організацій із науково-технічної діяльності у будівництві (організаційна на комунікаційна форми діяльності);
- організовує роботу з підготовки, перепідготовки та підвищення кваліфікації працівників сфери будівництва, житлово-комунального господарства (організаційна форма діяльності);

- узагальнює практику застосування законодавства з питань, що належать до його компетенції, розробляє пропозиції щодо вдосконалення законодавчих актів, актів Президента України, Кабінету Міністрів України та в установленому порядку вносить їх на розгляд Кабінету Міністрів України (нормотворча форма діяльності);

- інформує та надає роз'яснення щодо реалізації державної політики у відповідних сферах [7] (інформаційна форма діяльності).

Відповідно до п. 5 вказаного Положення Мінрегіон із метою організації своєї діяльності:

- здійснює в межах повноважень, передбачених законом, разом із відповідними центральними органами виконавчої влади контроль за цільовим та ефективним використанням державних коштів, передбачених для реалізації проектів, виконання програм (контрольно-наглядова форма діяльності);

- виступає державним замовником наукових досліджень комплексного характеру з питань, що належать до його компетенції (організаційна форма діяльності);

- сприяє відповідно до законодавства забезпеченню виконання міжнародних договорів України; забезпечує здійснення адаптації національного законодавства до законодавства ЄС з питань, що належать до його компетенції; здійснює в межах повноважень, передбачених законом, заходи щодо імплементації в національне законодавство положень міжнародних договорів, стороною яких є Україна (нормотворча та правозастосовна форми діяльності);

- координує та здійснює методичне забезпечення діяльності структурних підрозділів місцевих держадміністрацій, органів місцевого самоврядування, підприємств, установ та організацій із питань, що належать до його компетенції (комунікаційна форма діяльності);

- здійснює відповідно до законодавства функції з управління об’єктами державної власності, що належать до сфери його управління (організаційна форма діяльності);

- здійснює претензійно-позовну роботу, звертається до суду з позовами щодо захисту своїх прав та законних інтересів, а також інтересів держави у відповідних сферах (правозастосовна форма діяльності);

- здійснює в установленому порядку добір кадрів, формує кадровий резерв, організовує роботу з підготовки, перепідготовки та підвищення кваліфікації працівників Міністерства (організаційна форма діяльності);

- вживає заходів до створення та розвитку інформаційних систем і ресурсів, розробляє та 
впроваджує в межах повноважень, передбачених законом, сучасні інформаційно-комунікаційні технології (інформаційна форма діяльності);

- розглядає в установленому законодавством порядку звернення громадян із питань, що належать до його компетенції (інформаційна форма діяльності);

- оприлюднює інформацію про діяльність Міністерства, організовуе в установленому порядку виставкову та видавничу діяльність, проведення конкурсів, семінарів, конференцій, конгресів із питань, що належать до його компетенції (інформаційна форма діяльності);

- здійснює в межах повноважень, передбачених законом, контроль за станом охорони праці на підприємствах, в установах та організаціях, що належать до сфери його управління [7] (контрольно-наглядова форма діяльності).

Міністерство розвитку громад і територій під час виконання покладених на нього завдань взаємодіє з іншими державними органами, допоміжними органами і службами, утвореними Президентом України, тимчасовими консультативними, дорадчими та іншими допоміжними органами, утвореними Кабінетом Міністрів України, органами місцевого самоврядування, об'єднаннями громадян, громадськими спілками, профспілками та організаціями роботодавців, відповідними органами іноземних держав і міжнародних організацій, а також підприємствами, установами, організаціями (комунікаційна форма діяльності).

Проведене дослідження дало змогу сформулювати наведені нижче висновки. Форми діяльності Міністерства розвитку громад і територій регламентовані чинним законодавством, зокрема, Законом України «Про центральні органи виконавчої влади» та чинним Положенням про Міністерство регіонального розвитку, будівництва та житлово-комунального господарства України. Форми діяльності Міністерства розвитку громад і територій доцільно поділити на чотири основні групи: правові (юридично-значущі) форми діяльності - нормотворчість (міжвідомча і відомча), правозастосування (посвідчення юридичних фактів, вирішення юридичних конфліктів та притягнення винуватих осіб до юридичної відповідальності), установча, контрольно-наглядова діяльність та інтерпретаційна; організаційні - адміністративно-господарська (матеріально-технічне забезпечення діяльності міністерства) та організаційно-розпорядча діяльність (кадрове забезпечення діяльності міністерства та оперативне управління його діяльністю); інформаційні - оприлюднення публічної формації про діяльність міністерства (прес-конференції, прес-релізи, інформаційні стенди, ведення офіційного веб-сайту) та відповіді на звернення громадян та інформаційні запити щодо доступу до публічної формації; комунікаційні форми діяльності - налагодження комунікаційних зв'язків між міністерством та іншими органами публічної адміністрації та обмін інформаційними повідомленнями в рамках єдиноїінформаційної системи електронного документообігу.

Сучасні процеси тотальної інформатизації вимагають постійного удосконалення інформаційних та комунікаційних форм діяльності Міністерства розвитку громад і територій шляхом повного переходу на електронний документообіг та відмови від «паперової» бюрократії, що є цілком можливим завдяки використанню технологій цифрового підпису та зростаючим потужностям інформаційних мереж. Вказані зміни потребують нормативної регламентації на рівні відомчих нормативно-правових актів міністерства. Не менш важливим $€$ продовження політики децентралізації, надання максимальної автономії органам місцевого самоврядування із збереженням за органами виконавчої влади лише контрольно-наглядових повноважень.

\section{Jimepamypa}

1. Програма діяльності Кабінету Міністрів України, затверджена Постановою Кабінету Міністрів України від 29 вересня 2019 р. № 849. URL: https://program. kmu.gov.ua/

2. Железняк Н.А. Правові та організаційні форми діяльності Міністерства юстиції України у здійсненні державної правової політики (теоретичні та практичні питання). Наукові записки. 2001. Том. 19. Спеціальний випуск. С. 226-231.

3. Предместнікова О. Особливості організаційних і матеріально-технічних форм діяльності органів юстиції України. Адміністративне право і процес. 2016. № 12. С. $146-151$.

4. Слинько Д.В. Форми здійснення правотворчого процесу в діяльності Міністерства внутрішніх справ України. Право і безпека. 2017. № 3 (66). С. 52-56.

5. Державне будівництво і місцеве самоврядування в Україні : підручник / I.I. Бодрова, С.В. Болдирєв, В.О. Величко та ін.; за ред. С.Г. Серьогіної; 4-те вид., переробл. та допов. Харків : Право, 2017. 392 с.

6. Про центральні органи виконавчої влади : Закон України від 17 березня 2011 р. № 3166-VI. Дата оновлення: 25.09.2019 p. URL: https://zakon.rada.gov.ua/ laws/show/3166-17.

7. Про затвердження Положення про Міністерство регіонального розвитку, будівництва та житлово-комунального господарства України : Постанова Кабінету Міністрів України від 30 квітня 2014 р. № 197. Дата оновлення: 23.01 .2019 p. URL: https://zakon.rada.gov. ua/laws/show/197-2014-п. 


\section{Анотація}

Пєший О. В. Форми діяльності Міністерства розвитку громад і територій. - Стаття.

У науковій публікації досліджуються форми діяльності Міністерства розвитку громад і територій. Формулюється висновок, що форми діяльності міністерства доцільно поділити на чотири основні групи: правові форми діяльності (нормотворчість, правозастосування, установча, контрольно-наглядова діяльність та інтерпретаційна); організаційні (адміністративно-господарська та організаційно-розпорядча діяльність); інформаційні та комунікаційні форми діяльності.

Зазначається, що форми діяльності Міністерства розвитку громад і територій регламентовані чинним законодавством, зокрема, Законом України «Про центральні органи виконавчої влади» та чинним Положенням про Міністерство регіонального розвитку, будівництва та житлово-комунального господарства України. Крім того, форми діяльності Міністерства розвитку громад і територій відповідають, завданням будь-якого міністерства, які визначені у ст. 7 Закону України «Про центральні органи виконавчої влади», згідно з якою основними завданнями міністерства як органу, що забезпечує формування та реалізує державну політику в одній чи кількох сферах, є: забезпечення нормативно-правового регулювання; визначення пріоритетних напрямів розвитку; інформування та надання роз'яснень щодо здійснення державної політики; узагальнення практики застосування законодавства, розроблення пропозицій щодо його вдосконалення та внесення в установленому порядку проектів законодавчих актів.

Сучасні процеси тотальної інформатизації вимагають удосконалювати інформаційні та комунікаційні форми діяльності Міністерства розвитку громад і територій шляхом повного переходу на електронний документообіг та відмови від "паперової» бюрократії, що є цілком можливим із використанням технологій цифрового підпису та зростаючою потужністю інформаційних мереж.

Ключові слова: форми діяльності, державне управління, громада, адміністративне право, нормотворчість, правозастосування, організаційна діяльність, інформаційна діяльність, комунікаційна діяльність.

\section{Summary}

Peshiy 0. V. Forms of activity of the Ministry of Communities and Territories Development. - Article.

In the scientific publication the forms of activity of the Ministry of Community and Territory Development are analyzed. The conclusion is formulated that it is advisable to divide the forms of activity of the ministry into four groups: legal forms of activity (rule-making, law enforcement, constituent, control and supervisory and interpretative activities), organizational (administrative, economic and organizational and administrative activities), information and communication forms of activity.

It is noted that the forms of activity of the Ministry of Communities and Territories Development are regulated by the current legislation, in particular, the Law of Ukraine "On Central Executive Bodies" and the current Regulation on the Ministry of Regional Development, Construction and Housing and Communal Services of Ukraine. In addition, the forms of activity of the Ministry of Development of Communities and Territories correspond to the tasks of any ministry, which are defined in Art. 7 of the Law of Ukraine "On Central Executive Bodies", according to which the main tasks of the Ministry as an authority that provides for the formation and implementation of state policy in one or more areas are: ensuring regulatory and legal regulation; definition of priority directions of development; informing and clarifying public policy; generalization of the practice of application of legislation, development of proposals for its improvement and drafting of legislative acts in the established order.

Modern processes of total informatization require improvement of information and communication forms of activity of the Ministry of Communities and Territories Development through full transition to electronic document circulation and elimination of "paper" bureaucracy, which is quite possible with the use of digital signature technologies and increasing power of information network.

Key words: forms of activity, public administration, community, administrative law, rulemaking, law enforcement, organizational activities, information activities, communication activities. 